Article

\title{
Emotional Status and Productivity: Evidence from the Special Economic Zone in Laos
}

\author{
Yoshihiko Kadoya ${ }^{\mathbb{D}}$, Mostafa Saidur Rahim Khan *(D), Somtip Watanapongvanich and \\ Punjapol Binnagan
}

School of Economics, Hiroshima University, Hiroshima 739-8525, Japan; ykadoya@hiroshima-u.ac.jp (Y.K.); somtip.w@gmail.com (S.W.); punjapol.punjapol@gmail.com (P.B.)

* Correspondence: khan@hiroshima-u.ac.jp

Received: 17 January 2020; Accepted: 17 February 2020; Published: 19 February 2020

\begin{abstract}
Employee productivity is a well-studied area, which has been explained in various dimensions. However, there is insufficient research on how workers' on-job emotional status relates to productivity. This study examined the relationship between workers' emotional states and productivity by assessing on-job emotionality recorded using a specially designed wearable biometric device. The experiment was conducted at KP Beau Lao Co. Ltd., a Japanese plastic toys and cosmetic products company in Savannakhet province in Southwestern Laos. Participants were 15 plastic toy painters. Mental status, daily output, and other issues were recorded for three consecutive working days. Using random effects panel regression models, we examined how productivity, operationalized as the log of daily output, was related to workers' emotional states, including the amount of time workers reported being happy, angry, relaxed, and sad. We controlled for conversation time, heart rate, and other demographic features. The results revealed that happiness, and no other emotional state, was significantly and positively related to productivity. Such findings suggested that workers' emotional states must be addressed as part of an organization's operational strategy to ensure higher productivity.
\end{abstract}

Keywords: productivity; emotional status; wearable biometric device; conversation time; heart rate; Japan

\section{Introduction}

Improving employee productivity is an important consideration for the overall wellbeing of an organization. Productivity is related to not only the organization's profitability but also its operations and human resource management. Because of its multidimensional importance, numerous studies have been conducted to observe what affects employee productivity and how it could be improved. Previous studies have already documented how employee productivity is linked to job-related terms and conditions, technological advancement, and employees' demographic, socioeconomic, and psychological factors. Recent research shows that employees' mental health status and psychological conditions affect their productivity. However, there is inadequate research on how employees' on-job emotional conditions affect their productivity. On-job emotional condition is important because it defines how employees will apply their acquired knowledge in the workplace. Thus, the present study examined the relationship between employee productivity and on-job emotional states. A unique dataset that tracks both employees' emotional states during working hours within a factory and their quantifiable output on a real-time basis were used in the study.

Productivity refers to how efficiently workers produce goods or services to achieve a company's objectives. Workers' productivity can be measured as an output (e.g., unit of sales or volume of production) relative to an input (e.g., the number of hours worked or the cost of labor). Mathis and 
Jackson [1] referred to productivity as a measure of quantity and quality of work done considering the cost of the resource used to do the work. Higher productivity does not necessarily only mean greater output; it also means fewer people or less money or less time are used to produce the same amount. Mathis and Jackson [1] identified three factors, which contribute to workers' productivity: the ability to do the work, the level of effort made, and support given to them. Ferreira and Du Plessis [2] also considered that the time an employee spends performing a job is an important component of productivity. Higher productivity can help reduce costs, increase profitability, expand operations, satisfy stakeholders, and ensure a place in the competitive marketplace [3-5]. As a result, many organizations automate their production process and employ new technologies to improve productivity. Oliner and Sichel [6] provided evidence that the advancement of information technology during the second half of the 1990s ensured sustained growth in productivity in the US. Relich [7] reported that investment in information and communication technologies at the company level positively affects labor productivity in EU countries. Apart from investment in technology and innovation, to improve productivity, organizations invest in human resources programs, such as organizing training, increasing facilities and benefits, providing favorable job-related terms and conditions, implementing worker monitoring devices, and so on. Perhaps the most important and most closely scrutinized of all productivity resources are human resources [1]. However, compared to the aforementioned human resources development and monitoring issues, the psychology and emotions of employees have received less emphasis in the analyses of employee productivity. Sharma and Sharma [8] argued that while the physical presence of an employee is needed for productivity, his/her mental presence is equally important.

Previous studies provided evidence for the factors that explain productivity from different dimensions. In terms of on-job conditions, employee productivity can be explained as a means to assess issues that motivate workers to optimally engage in productive activity. Job security, organizational justice, fairness, benefits, and prosocial spending are a few factors that motivate employees to perform and improve their productivity [9-12]. Anwar, Aslam, and Tariq [13] and Holzer [14] observed that previous experience, tenure in the current job, and types of job contracts have significant positive effects on employee productivity. The use of technology in the workplace is another important aspect of productivity. For instance, computers, Internet access, robotics, and other forms of automation help improve productivity in the workplace. Basu, Fernald, and Shapiro [15] revealed that productivity growth is positively related to technological changes, both in the manufacturing and non-manufacturing sectors. Hempell [16], the Productivity Commission of Australia [17], and Gavin [18] have noted how information and communication technology help to improve productivity within each organization and in the overall job sector.

A different strand of studies provided evidence that workers' demographic and socioeconomic attributes, such as age, education, income, assets, and social status, influence their productivity. So far, studies on the relationship between age and productivity have provided mixed evidence. Skirbekk [19], Dostie [20], Lallemand and Rycx [21], and Garibaldi, Oliveira Martins, and van Ours [22] observed a non-linear and complex relationship between age and productivity whereby productivity declines after a certain age. However, against this complex and non-linear relationship, there is evidence for a flat or even positive relationship between age and productivity. Aubert and Crépon [23] found that productivity peaks at the age of 40-45 and remains stable thereafter, and Göbel and Zwick [24] showed a flat age-productivity relationship between 40 and 60 years of age. Börsch-Supan and Weiss [25] found that productivity continues to increase until the age of 65. In addition to the mixed evidence on how productivity evolves with age, previous literature provides mixed evidence on how aging affects productivity at the micro-level (worker's productivity) and at the macro-level (aggregate productivity). Calvo-Sotomayor, Laka, and Aguado [26] provided evidence that an increase in the older workforce reduced an increase in productivity, but the influence would be less observed due to the development of capital and knowledge-intensive sectors. Mahlberg et al. [27] also reported that a larger share of older employees was not associated with reduced productivity at the firm level. 
However, there is a concern for reduced productivity at the aggregate level due to an increase in the aging population [28]. Wu and Cheng [29] found that gender equality in the workforce could also increase productivity growth. Jones [30] reported that workers' education is positively related to productivity. Belorgey, Lecat, and Maury [31] provided evidence that human capital, as proxied by education, is one of the most important factors in determining overall productivity. Saxena [32] further observed that workforce diversity in terms of age, cultural background, physical abilities, race, religion, sex, and sexual orientation has a positive impact on productivity.

Recent studies have revealed that workers' mental health conditions and related risk factors are also associated with workplace productivity [33-38]. Workers' psychological states, such as positive attitudes and mental peace, can also influence productivity. DiMaria et al. [39], Frey [40], and Tenney et al. [41] revealed that positive thinkers, namely happy and satisfied workers, are more likely to perform well. Studies have also emphasized how an employee's health and wellbeing impact productivity. Neumann and Dul [42], as well as Ødegaard and Roos [43], found that healthier employees are more productive. Gubler, Larkin, and Pierce [44] provided evidence that implementing a corporate wellness program improved employee productivity. Recognizing the importance of workers' mental health and wellness, organizations have increased investment in health and wellness-related programs [45].

The discussion in the previous paragraph suggests that physical and mental health conditions are related to productivity, but the relationship between employees' emotions and productivity has not been studied extensively. Emotions are states of consciousness, comprising feelings, physiological responses, and behavioral expressions, which often occur simultaneously [46]. Although we are not always aware of it, emotions play a critical role in our everyday behavioral tasks [37]. Current workplaces have increased interactions between humans and machines, and emotions play an important role in determining performance $[38,47]$. How workers interact with machines can depend on their emotional state. For instance, enthusiasm could help make tasks easier, while lethargy could make tasks more difficult. Yang and Hung [48] conducted an experiment using an emotion induction technique to assess how emotional states affect performance. The results revealed that happy people tend to value long-term rewards and assign greater utility to effort. Oswald, Proto, and Sgroi [49] also found that happy people were $12 \%$ more productive than others. Given that emotions change throughout the day [47], it is important to track these emotional states and organize tasks accordingly [37].

Although there have been several studies relating productivity to employees' emotions, there is a dearth of research focusing on how a worker's on-job emotional status relates to productivity. Thus far, studies have measured emotions passively based on employees' actions, such as by analyzing the text, content, and tone. Thus, how employees' on-job emotional states affect their productivity is still not evident. The use of wearable biometric devices, which can track an employee's emotional states, provides an opportunity to examine more objective components of the emotion-productivity link. To the best of our knowledge, this was the first study to examine how employees' emotional states affect productivity, using the quantity of daily output as an outcome. The present study controlled for other biometric and known demographic factors that could influence emotionality and productivity. It contributed to the existing literature in several ways. It provided evidence of how emotional states were directly related to productivity and which specific emotional states were related and unrelated to productivity. It also suggested how employees could overcome adverse emotional states to enhance productivity. Finally, the evidence from the study could be used by management to improve workflows, allocation of break times, and performance targets.

\section{Data and Methodology}

\subsection{Sample Selection, Variable Definitions, and Measurement Issues}

Unskilled line workers from KP Beau Lao Co. Ltd, a Japanese plastic toys and cosmetic products company in Savannakhet province in Southwestern Laos, participated in this study. Although the production of toys and cosmetic goods is complicated and requires a great deal of technical knowledge, 
the workers in the present study were focused on a specific, unskilled task that could be easily quantified. This was intended to reduce the role of skill level in productivity to adequately compare work output as a function of emotionality. Our sample comprised of 15 workers. They had to answer a questionnaire and wear a wristband biometric sensor that could capture physiological responses. The device, Silmee ${ }^{\mathrm{TM}} \mathrm{W} 20$, is produced by the TDK Corporation Tokyo, Japan. The device measures $20.5 \times 65 \times 12.5 \mathrm{~mm}$ and weighs about 29.5 grams. It has built-in sensors to detect acceleration, pulse wave, environmental ultraviolet light, temperature, and sound through which it continuously records physical activity, beat-to-beat pulse intervals, skin temperature, and sleep. The ethics committee at Hiroshima University, Japan, approved the study protocol.

Workers were monitored for three working days (March 11 to 13, 2019). On the first day of the experiment, participants were informed about the purpose, methods, and privacy issues related to the study. All of them agreed to participate and signed an informed consent form. Participants were also informed that they could withdraw at any time. They then provided information on sex, age, education, work experience, living arrangement, and commute time to work. Finally, all workers wore the biometric sensor device and continued working on their painting tasks.

The emotional measures were based on the circumplex model of emotion [50], which postulates that emotions are distributed along arousal and valence dimensions. Arousal represents the vertical axis, and valence represents the horizontal axis, while the center represents a neutral valence [51]. According to this model, emotional states represent different levels of activation and pleasantness/unpleasantness. We focused on the emotions signifying happy, angry, relaxed, and sad states. We also considered neutral as the absence of any distinct emotion. Emotional states were measured through a complex process of considering beat-to-beat pulse intervals via custom software developed by NEC Corporation Tokyo, Japan. The condition of each subject's automatic nervous system was evaluated by observing the R-R interval (RRI), which indicates the heartbeat variability. The software uses a specific algorithm pattern of the subject's heartbeat variability to differentiate among emotional states. It is already documented that RRI is associated with the condition of one's automatic nervous system, representing emotional status. Choi et al. [52] provided evidence that heart rate variability could be used to adequately evaluate human emotion. Valenza, Antonio, and Enzo [53] and Lane et al. [54] also confirmed that heart rate variability could be an objective tool to assess emotional responses. The device used in the present study also collected data on heart rate per minute, skin temperature, the amount of ultraviolet light received, conversation time (i.e., speaking during a specific time interval), number of steps in a minute, and activity type (not moving, walking, running, light-medium-heavy exercise, and sleep state).

To measure workers' productivity, we examined the full work shift from 7:40 AM to 16:40 PM, with three breaks. Work hours were separated into four segments: (1) 7:40-9:30 AM, (2) 9:40-11:30 AM, (3) 12:10-14:10 PM, and (4) 14:20-16:20 PM. A manager kept track of the number of finished toys each worker painted during each shift. All aforementioned variables and definitions are as shown in Table 1. 
Table 1. Definition of Variables.

\begin{tabular}{cc}
\hline Variables & Definition \\
\hline Output & Total finished toys painted in a day, excluding overtime \\
Log of output & Log of total finished toys painted in a day, excluding overtime \\
Happy emotion & Percentage of working hours in which workers remain in a happy state \\
Angry emotion & Percentage of working hours in which workers remain in an angry state \\
Relaxed emotion & Percentage of working hours in which workers remain in a relaxed state \\
Sad emotion & Percentage of working hours in which workers remain in a sad state \\
Neutral emotion & Percentage of working hours in which workers do not show any particular emotion \\
Conversation & Percentage of working hours that workers spend in conversation \\
Heart rate & Average heart rate per minute during working hours \\
Sex & Dummy variable: 1 = female and 0 = male \\
Age & Age of workers in years \\
Experience & Work experience in painting plastic toys (in months) \\
Schooling & Years of education \\
Accommodation & Commuting time from home to company (minutes) \\
Commuting time & Dummy variable: $1=$ living at company's accommodation, 0 otherwise \\
\hline
\end{tabular}

\subsection{Data}

The main variables of interest in this study were emotional status, conversation time, and heart rate during working hours, along with demographic data. We treated emotional status variables and conversation time as percentages of the working hours. For heart rate, we used average beats per minute.

Descriptive statistics are displayed in Table 2. The average daily output per worker was 1789 $(S D=729, \operatorname{Max}=3490$, Min = 650). The first day output $(M=1107, S D=423$, Max $=1960, \operatorname{Min}=$ $650)$ was much lower than the output on days $2(M=2165, \mathrm{SD}=615, \mathrm{Max}=3490$, Min $=1400)$ and $3(\mathrm{M}=2120, \mathrm{SD}=589, \mathrm{Max}=3220$, Min $=1340)$. This could be because the study started earlier during the second and third days. The output of the first day only included segments 3 to 5 . Overall, workers reported mostly a happy mood $(\mathrm{M}=9 \%$ of total working hours, $\mathrm{SD}=10 \%$ of total working hours, Max $=54 \%$ of total working hours, Min $=0 \%$ of total working hours) compared to angry ( $\mathrm{M}=$ $6 \%, \mathrm{SD}=5 \%, \operatorname{Max}=24 \%$, Min $=0 \%)$ and relaxed states $(\mathrm{M}=1 \%, \mathrm{SD}=1 \%, \mathrm{Max}=8 \%, \operatorname{Min}=0 \%)$. Sad moods were negligible in the sample. Workers seemed to be in a neutral mood most of the time $(\mathrm{M}=85 \%, \mathrm{SD}=14 \%, \mathrm{Max}=100 \%$, Min $=19 \%)$. Workers also spent a considerable amount of time in conversation $(\mathrm{M}=14 \%, \mathrm{SD}=9 \%, \mathrm{Max}=31 \%$, Min $=0 \%)$. Average heart rate was 86.63 beats per minute (SD = 15, Max = 118, Min =59). Fourteen of the workers were women, with one male colleague; therefore, the gender distribution of the sample was not unbiased. However, this fact is justified by the overall gender distribution of KP Beau Lao Co. Ltd. Most of the workers in this company are female. Nonetheless, the gender distribution in our sample could have implications for the overall conclusion and generalizability of the study. Average work age was 22.67 years $(\mathrm{SD}=3.11$, Max $=29$, Min $=19)$, and average work experience was 25.67 months $(S D=10.40$, Max $=48$, Min $=11$ ), with 8.80 years (SD $=3.32$, Max $=16$, Min =5) of schooling. Only one worker lived in the company's accommodation. Average commute time to work was 28 minutes $(\mathrm{SD}=14.17$, $\operatorname{Max}=50, \operatorname{Min}=0)$. 
Table 2. Descriptive Statistics.

\begin{tabular}{|c|c|c|c|c|c|c|}
\hline Variable & & Observations & $\begin{array}{c}\text { Mean } \\
\text { (M) }\end{array}$ & $\begin{array}{l}\text { Standard } \\
\text { Deviation } \\
\text { (SD) }\end{array}$ & Min & Max \\
\hline \multirow[t]{4}{*}{ Output } & Overall & 44 & 1789.55 & 729.73 & 650.00 & 3490.00 \\
\hline & Day 1 & 15 & 1107.33 & 423.40 & 650.00 & 1960.00 \\
\hline & Day 2 & 14 & 2165.71 & 615.24 & 1400.00 & 3490.00 \\
\hline & Day 3 & 15 & 2120.67 & 589.21 & 1340.00 & 3220.00 \\
\hline \multirow[t]{4}{*}{ Log of output } & Overall & 44 & 7.40 & 0.45 & 6.48 & 8.16 \\
\hline & Day 1 & 15 & 6.94 & 0.28 & 7.24 & 8.16 \\
\hline & Day 2 & 14 & 7.64 & 0.30 & 7.29 & 8.36 \\
\hline & Day 3 & 15 & 7.62 & 0.28 & 7.20 & 8.08 \\
\hline \multirow{4}{*}{ Happy } & Overall & 45 & 0.09 & 0.10 & 0.00 & 0.54 \\
\hline & Day 1 & 15 & 0.04 & 0.03 & 0.00 & 0.13 \\
\hline & Day 2 & 15 & 0.11 & 0.13 & 0.00 & 0.54 \\
\hline & Day 3 & 15 & 0.12 & 0.08 & 0.01 & 0.31 \\
\hline \multirow[t]{4}{*}{ Angry } & Overall & 45 & 0.06 & 0.05 & 0.00 & 0.24 \\
\hline & Day 1 & 15 & 0.03 & 0.02 & 0.00 & 0.07 \\
\hline & Day 2 & 15 & 0.07 & 0.06 & 0.01 & 0.24 \\
\hline & Day 3 & 15 & 0.07 & 0.06 & 0.00 & 0.17 \\
\hline \multirow[t]{4}{*}{ Relaxed } & Overall & 45 & 0.01 & 0.01 & 0.00 & 0.08 \\
\hline & Day 1 & 15 & 0.00 & 0.00 & 0.00 & 0.01 \\
\hline & Day 2 & 15 & 0.01 & 0.01 & 0.00 & 0.04 \\
\hline & Day 3 & 15 & 0.01 & 0.02 & 0.00 & 0.08 \\
\hline \multirow[t]{4}{*}{ Sad } & Overall & 45 & 0.00 & 0.00 & 0.00 & 0.01 \\
\hline & Day 1 & 15 & 0.00 & 0.00 & 0.00 & 0.00 \\
\hline & Day 2 & 15 & 0.00 & 0.00 & 0.00 & 0.01 \\
\hline & Day 3 & 15 & 0.00 & 0.00 & 0.00 & 0.01 \\
\hline \multirow[t]{4}{*}{ Neutral emotion } & Overall & 45 & 0.85 & 0.14 & 0.19 & 1.00 \\
\hline & Day 1 & 15 & 0.93 & 0.05 & 0.81 & 1.00 \\
\hline & Day 2 & 15 & 0.81 & 0.19 & 0.19 & 0.99 \\
\hline & Day 3 & 15 & 0.80 & 0.12 & 0.57 & 0.99 \\
\hline \multirow[t]{4}{*}{ Conversation } & Overall & 45 & 0.14 & 0.09 & 0.00 & 0.31 \\
\hline & Day 1 & 15 & 0.20 & 0.06 & 0.10 & 0.30 \\
\hline & Day 2 & 15 & 0.11 & 0.08 & 0.00 & 0.31 \\
\hline & Day 3 & 15 & 0.11 & 0.08 & 0.00 & 0.24 \\
\hline \multirow[t]{4}{*}{ Heart rate } & Overall & 45 & 86.63 & 15.55 & 59.69 & 118.29 \\
\hline & Day 1 & 15 & 91.80 & 12.59 & 70.21 & 112.19 \\
\hline & Day 2 & 15 & 83.09 & 17.60 & 59.69 & 116.38 \\
\hline & Day 3 & 15 & 85.01 & 15.69 & 66.37 & 118.29 \\
\hline Sex & Overall & 45 & 0.93 & 0.26 & 0 & 1 \\
\hline Age & Overall & 45 & 22.67 & 3.11 & 19 & 29 \\
\hline Experience & Overall & 45 & 25.67 & 10.40 & 11 & 48 \\
\hline Schooling & Overall & 45 & 8.8 & 3.32 & 5 & 16 \\
\hline Accommodation & Overall & 45 & 0.07 & 0.26 & 0 & 1 \\
\hline Commuting time & Overall & 45 & 28 & 14.17 & 0 & 50 \\
\hline
\end{tabular}

\subsection{Method}

The present study used a panel data analysis technique. The Breusch-Pagan Lagrange multiplier (LM) test was used to decide between a random-effects regression or ordinary least squares regression analysis. For the LM test, the null hypothesis states that variance across entities is zero (i.e., there is no significant difference across units). If the null hypothesis cannot be rejected, the random effects regression is inappropriate. However, if the null hypothesis is rejected, we can apply the Hausman test to decide between random and fixed effects regression analysis. Here, the null hypothesis states that the unobserved heterogeneous errors are not correlated with the regressors in the model. If the null hypothesis is not rejected, the random-effects model is suitable. 
Based on the LM and Hausman test, we chose the random effects regression model. This is because, in the present study, the chi-square statistic for the LM test was $7.21(\mathrm{p}<0.01)$. The Hausman test results provided a non-significant chi-square test result. Therefore, we could not reject the null hypothesis that there was no correlation between the unobserved heterogeneous effect and the regressors.

In the random effects panel regression model, we used worker productivity as the dependent variable and emotional states as the independent variable, controlling for the demographic and biometric factors. The regression equation is as follows:

$$
\begin{gathered}
\log \text { (output }_{\text {it }}=\beta_{0}+\beta_{1} \text { emotionalstatus }_{i t} \text { (happy, angry, relaxed, orsad) }+ \\
\beta_{2} \text { conversation }_{i t}+\beta_{3} \text { heart rate }_{i t}+\beta_{4} \text { female }_{i t}+\beta_{5} \text { age }_{i t}+\beta_{6} \text { experience }_{i t}+ \\
\beta_{7} \text { schooling }_{i t}+\beta_{8} \text { accomodation }_{i t}+\beta_{9} \text { commuting time }_{i t}+u_{i}+\varepsilon_{i t}
\end{gathered}
$$

where $u_{i}$ represents the unobserved heterogeneous factor, and $\varepsilon_{i t}$ is the error term.

\section{Empirical Results}

Several random-effects regression models were conducted to examine how emotional states are related to productivity after controlling for demographic and biometric factors. We developed four models, each of which controlled different variables. For example, in the first set of models, the log of daily output was the dependent variable, and happiness was the independent variable. In model $(1,1)$, we controlled for conversation and heart rate during the working hours. In model $(1,2)$, we controlled for all socioeconomic and biometric factors. In model $(1,3)$, we ignored sex and accommodation, owing to the lack of variability of these factors. In model $(1,4)$, we excluded sex, experience, and accommodation. The same set of model compositions was created to analyze sad, angry, and relaxed emotional states.

The regression results are reported in Table 3. Happiness was found to be significantly related to an increase in work output across all model specifications. Moreover, spending more time conversing with coworkers during work hours was significantly negatively related to work output across all models. In the happiness models, heart rate and demographic factors were insignificantly related to daily output. Since there is the possibility of multicollinearity between happiness and conversation time (i.e., greater conversation time in a work environment could be related to higher happiness), we conducted correlation and multicollinearity tests in the models. We included the results as supplementary materials rather than directly in the paper, to save on space. The results showed that multicollinearity between the variables was not significant, suggesting that the independent effects of happiness and conversation time on productivity were not biased. The correlation matrix showed a weak relationship between happiness and conversation while VIF (variance inflation factor) statistics of the independent variables were less than 10 , meaning that multicollinearity was not significant in the models.

Being in an angry emotional state was not significantly related to daily output in any model. However, as with the happiness models, time spent conversing was negatively associated with the work output. No other biometric or demographic variables were associated with daily output. Being in a relaxed emotional state was not significantly related to daily output across any of the four model specifications. As with the other two main models, time spent in conversation was significantly and negatively associated with daily output. No other variables significantly predicted work output.

Finally, there were no significant relationships between sadness and daily work output across any of the four model specifications. Time spent conversing, however, was negatively related to work output. No other factors significantly predicted work output. 
Table 3. Regression Results Random Effect Model.

\begin{tabular}{|c|c|c|c|c|c|c|c|c|}
\hline \multirow{2}{*}{ Variables } & \multicolumn{8}{|c|}{ Dependent Variable: Logarithm of Daily Output } \\
\hline & Model 11 & Model 12 & Model 13 & Model 14 & Model 21 & Model 22 & Model 23 & Model 24 \\
\hline Happy & $\begin{array}{l}2.246^{* * *} \\
(0.7690)\end{array}$ & $\begin{array}{l}2.019^{* *} \\
(0.8630)\end{array}$ & $\begin{array}{l}2.312^{* * * *} \\
(0.7930)\end{array}$ & $\begin{array}{c}2.293^{* * *} \\
(0.7850)\end{array}$ & & & & \\
\hline Angry & & & & & $\begin{array}{c}2.266 \\
(1.4210)\end{array}$ & $\begin{array}{c}2.64 \\
(1.6310)\end{array}$ & $\begin{array}{c}2.198 \\
(1.6500)\end{array}$ & $\begin{array}{c}2.449 \\
(1.5510)\end{array}$ \\
\hline Conversation & $\begin{array}{c}-2.701^{* * * *} \\
(0.6440)\end{array}$ & $\begin{array}{c}-2.701 * * * \\
(0.7190)\end{array}$ & $\begin{array}{c}-2.745^{* * *} \\
(0.6770)\end{array}$ & $\begin{array}{c}-2.731^{* * * *} \\
(0.6730)\end{array}$ & $\begin{array}{c}-2.836^{* * * *} \\
(0.6880)\end{array}$ & $\begin{array}{c}-2.765^{* * * *} \\
(0.7500)\end{array}$ & $\begin{array}{c}-2.776^{* * * *} \\
(0.7660)\end{array}$ & $\begin{array}{c}-2.793^{* * * *} \\
(0.7430)\end{array}$ \\
\hline Heart rate & $\begin{array}{l}0.00039 \\
(0.0031)\end{array}$ & $\begin{array}{c}-0.000124 \\
(0.0034)\end{array}$ & $\begin{array}{c}0.000598 \\
(0.0031)\end{array}$ & $\begin{array}{c}0.000549 \\
(0.0031)\end{array}$ & $\begin{array}{l}-0.0012 \\
(0.0034)\end{array}$ & $\begin{array}{c}-0.00183 \\
(0.0035)\end{array}$ & $\begin{array}{l}-0.0013 \\
(0.0036)\end{array}$ & $\begin{array}{c}-0.00123 \\
(0.0035)\end{array}$ \\
\hline Female & & $\begin{array}{c}0.319 \\
(0.4120)\end{array}$ & & & & $\begin{array}{c}0.436 \\
(0.4230)\end{array}$ & & \\
\hline Age & & $\begin{array}{l}-0.0173 \\
(0.0325)\end{array}$ & $\begin{array}{l}-0.0188 \\
(0.0393)\end{array}$ & $\begin{array}{l}-0.0189 \\
(0.0351)\end{array}$ & & $\begin{array}{l}-0.0126 \\
(0.0334)\end{array}$ & $\begin{array}{l}-0.0137 \\
(0.0320)\end{array}$ & $\begin{array}{l}-0.0123 \\
(0.0319)\end{array}$ \\
\hline Experience & & $\begin{array}{c}-0.000509 \\
(0.0101)\end{array}$ & $\begin{array}{c}-0.000114 \\
(0.0113)\end{array}$ & & & $\begin{array}{l}0.00226 \\
(0.0107)\end{array}$ & $\begin{array}{c}0.000541 \\
(0.0096)\end{array}$ & \\
\hline Schooling & & $\begin{array}{c}0.0128 \\
(0.0375)\end{array}$ & $\begin{array}{l}0.00968 \\
(0.0368)\end{array}$ & $\begin{array}{l}0.00978 \\
(0.0325)\end{array}$ & & $\begin{array}{c}0.0187 \\
(0.0384)\end{array}$ & $\begin{array}{c}0.0074 \\
(0.0301)\end{array}$ & $\begin{array}{l}0.00655 \\
(0.0293)\end{array}$ \\
\hline Accommodation & & $\begin{array}{c}0.361 \\
(0.4980)\end{array}$ & & & & $\begin{array}{c}0.644 \\
(0.4970)\end{array}$ & & \\
\hline Commuting Time & & $\begin{array}{l}0.00627 \\
(0.0094)\end{array}$ & $\begin{array}{c}0.000223 \\
(0.0082)\end{array}$ & $\begin{array}{c}0.000202 \\
(0.0075)\end{array}$ & & $\begin{array}{l}0.00817 \\
(0.0096)\end{array}$ & $\begin{array}{c}-0.00177 \\
(0.0069)\end{array}$ & $\begin{array}{c}-0.00209 \\
(0.0071)\end{array}$ \\
\hline Constant & $\begin{array}{c}7.555^{* * *} \\
(0.2860)\end{array}$ & $\begin{array}{l}7.415^{* * *} \\
(0.8670)\end{array}$ & $\begin{array}{l}7.875^{* * *} \\
(0.8550)\end{array}$ & $\begin{array}{l}7.878^{* * *} \\
(0.7870)\end{array}$ & $\begin{array}{l}7.779 * * * \\
(0.2940)\end{array}$ & $\begin{array}{l}7.188^{* * *} \\
(0.9130)\end{array}$ & $\begin{array}{l}8.064^{* * *} \\
(0.7350)\end{array}$ & $\begin{array}{l}8.046^{* * *} \\
(0.7250)\end{array}$ \\
\hline Observations & 44 & 44 & 44 & 44 & 44 & 44 & 44 & 44 \\
\hline Number of id & 15 & 15 & 15 & 15 & 15 & 15 & 15 & 15 \\
\hline Sigma & 0.4080 & 0.3770 & 0.4670 & 0.4460 & 0.3750 & 0.3780 & 0.3620 & 0.3820 \\
\hline sigma_u & 0.2980 & 0.2550 & 0.3760 & 0.3480 & 0.2480 & 0.2520 & 0.2280 & 0.2590 \\
\hline sigma_e & 0.2780 & 0.2780 & 0.2780 & 0.2780 & 0.2810 & 0.2810 & 0.2810 & 0.2810 \\
\hline r2within & 0.5820 & 0.5790 & 0.5830 & 0.5830 & 0.5440 & 0.5500 & 0.5430 & 0.5490 \\
\hline r2bw & 0.0410 & 0.1560 & 0.0629 & 0.0632 & 0.0000 & 0.1070 & 0.0060 & 0.0027 \\
\hline r2overall & 0.3140 & 0.3710 & 0.3300 & 0.3300 & 0.2230 & 0.3180 & 0.2410 & 0.2350 \\
\hline chi2 & 37.040 & 31.880 & 37.760 & 37.600 & 25.490 & 26.980 & 22.290 & 24.870 \\
\hline$p$-value & 0.0000 & 0.0002 & 0.0000 & 0.0000 & 0.0000 & 0.0014 & 0.0023 & 0.0004 \\
\hline
\end{tabular}


Table 3. Cont.

\begin{tabular}{|c|c|c|c|c|c|c|c|c|}
\hline \multirow{2}{*}{ Variables } & \multicolumn{8}{|c|}{ Dependent Variable: Logarithm of Daily Output } \\
\hline & Model 31 & Model 32 & Model 33 & Model 34 & Model 41 & Model 42 & Model 43 & Model 44 \\
\hline Relaxed & $\begin{array}{c}6.186 \\
(4.0970)\end{array}$ & $\begin{array}{c}5.893 \\
(4.2990)\end{array}$ & $\begin{array}{c}6.523 \\
(4.3760)\end{array}$ & $\begin{array}{c}6.484 \\
(4.2300)\end{array}$ & & & & \\
\hline Sad & & & & & $\begin{array}{c}8.562 \\
(23.3000)\end{array}$ & $\begin{array}{c}7.775 \\
(24.2300)\end{array}$ & $\begin{array}{c}7.655 \\
(23.9900)\end{array}$ & $\begin{array}{c}7.686 \\
(23.9700)\end{array}$ \\
\hline Conversation & $\begin{array}{c}-2.840^{* * * *} \\
(0.6910)\end{array}$ & $\begin{array}{c}-2.999 * * * \\
(0.7350)\end{array}$ & $\begin{array}{c}-2.928^{* * * *} \\
(0.7420)\end{array}$ & $\begin{array}{c}-2.942 * * * \\
(0.7290)\end{array}$ & $\begin{array}{c}-2.948^{* * * *} \\
(0.7190)\end{array}$ & $\begin{array}{c}-3.083^{* * * *} \\
(0.7640)\end{array}$ & $\begin{array}{c}-3.100 * * * \\
(0.7580)\end{array}$ & $\begin{array}{c}-3.063^{* * *} \\
(0.7540)\end{array}$ \\
\hline Heart rate & $\begin{array}{c}-0.000509 \\
(0.0034)\end{array}$ & $\begin{array}{c}-0.000605 \\
(0.0035)\end{array}$ & $\begin{array}{c}-0.000217 \\
(0.0036)\end{array}$ & $\begin{array}{c}-0.000178 \\
(0.0035)\end{array}$ & $\begin{array}{c}-0.000851 \\
(0.0034)\end{array}$ & $\begin{array}{c}-0.00103 \\
(0.0036)\end{array}$ & $\begin{array}{c}-0.000569 \\
(0.0035)\end{array}$ & $\begin{array}{c}-0.000586 \\
(0.0035)\end{array}$ \\
\hline Female & & $\begin{array}{c}0.333 \\
(0.4630)\end{array}$ & & & & $\begin{array}{c}0.372 \\
(0.4890)\end{array}$ & & \\
\hline Age & & $\begin{array}{l}-0.0259 \\
(0.0371)\end{array}$ & $\begin{array}{l}-0.0263 \\
(0.0338)\end{array}$ & $\begin{array}{l}-0.0269 \\
(0.0320)\end{array}$ & & $\begin{array}{l}-0.0166 \\
(0.0387)\end{array}$ & $\begin{array}{l}-0.0165 \\
(0.0390)\end{array}$ & $\begin{array}{l}-0.0197 \\
(0.0350)\end{array}$ \\
\hline Experience & & $\begin{array}{c}0.000643 \\
(0.0115)\end{array}$ & $\begin{array}{c}-0.000628 \\
(0.0097)\end{array}$ & & & $\begin{array}{c}-0.00166 \\
(0.0120)\end{array}$ & $\begin{array}{c}-0.003 \\
(0.0112)\end{array}$ & \\
\hline Schooling & & $\begin{array}{c}0.0185 \\
(0.0419)\end{array}$ & $\begin{array}{l}0.00564 \\
(0.0313)\end{array}$ & $\begin{array}{l}0.00638 \\
(0.0295)\end{array}$ & & $\begin{array}{c}0.0162 \\
(0.0447)\end{array}$ & $\begin{array}{l}0.00398 \\
(0.0370)\end{array}$ & $\begin{array}{l}0.00745 \\
(0.0329)\end{array}$ \\
\hline Accommodation & & $\begin{array}{c}0.615 \\
(0.5430)\end{array}$ & & & & $\begin{array}{c}0.631 \\
(0.5740)\end{array}$ & & \\
\hline Commuting Time & & $\begin{array}{c}0.0106 \\
(0.0103)\end{array}$ & $\begin{array}{c}0.0011 \\
(0.0070)\end{array}$ & $\begin{array}{l}0.00125 \\
(0.0068)\end{array}$ & & $\begin{array}{c}0.0106 \\
(0.0109)\end{array}$ & $\begin{array}{c}0.000913 \\
(0.0082)\end{array}$ & $\begin{array}{l}0.00134 \\
(0.0075)\end{array}$ \\
\hline Constant & $\begin{array}{l}7.809 * * * \\
(0.2950)\end{array}$ & $\begin{array}{l}7.597^{* * *} \\
(0.9690)\end{array}$ & $\begin{array}{l}8.325^{* * *} \\
(0.7390)\end{array}$ & $\begin{array}{l}8.312 * * * \\
(0.7220)\end{array}$ & $\begin{array}{l}7.871^{* * *} \\
(0.2990)\end{array}$ & $\begin{array}{l}7.492 * * * \\
(1.0230)\end{array}$ & $\begin{array}{l}8.257^{* * *} \\
(0.8510)\end{array}$ & $\begin{array}{l}8.207^{* * *} \\
(0.7860)\end{array}$ \\
\hline Observations & 44 & 44 & 44 & 44 & 44 & 44 & 44 & 44 \\
\hline Number of id & 15 & 15 & 15 & 15 & 15 & 15 & 15 & 15 \\
\hline Sigma & 0.4050 & 0.4500 & 0.4190 & 0.4260 & 0.4260 & 0.4710 & 0.4810 & 0.4610 \\
\hline sigma_u & 0.2580 & 0.3240 & 0.2800 & 0.2900 & 0.2840 & 0.3470 & 0.3610 & 0.3340 \\
\hline sigma_e & 0.3130 & 0.3130 & 0.3130 & 0.3130 & 0.3180 & 0.3180 & 0.3180 & 0.3180 \\
\hline r2within & 0.4650 & 0.4680 & 0.4650 & 0.4650 & 0.4530 & 0.4530 & 0.4540 & 0.4540 \\
\hline $\mathrm{r} 2 \mathrm{bw}$ & 0.1080 & 0.3050 & 0.1420 & 0.1410 & 0.0599 & 0.2390 & 0.0784 & 0.0754 \\
\hline r2overall & 0.3000 & 0.3930 & 0.3280 & 0.3280 & 0.2510 & 0.3440 & 0.2680 & 0.2650 \\
\hline chi2 & 24.420 & 26.500 & 23.800 & 24.710 & 21.920 & 23.760 & 22.450 & 22.270 \\
\hline$p$-value & 0.0000 & 0.0017 & 0.0012 & 0.0004 & 0.0001 & 0.0047 & 0.0021 & 0.0011 \\
\hline
\end{tabular}

Notes: ${ }^{* * *}=1 \%$ level of significance; ${ }^{* *}=5 \%$ level of significance. The standard errors are in parentheses. 


\section{Discussion}

Workers' productivity is an important issue for any business organization interested in increasing output, reducing costs, and making profits. Productivity analyses are an often-studied area within the field of production and operational management. Previous studies have examined workers' productivity from the viewpoint of job-related issues [10-13], technology [15,18], worker demographics and socioeconomic features [7,19,22,31], and worker health conditions [34-36,42-45,55,56]. Although previous research has explored several factors contributing to workers' productivity, few studies have examined the link between workers' on-job emotional states and productivity. The present study examined how workers' emotional states (i.e., happiness, anger, relaxation, and sadness) were related to productivity after controlling for various biometric and demographic features.

The random-effects panel regression results revealed that being happy in the workplace was significantly and positively related to productivity. Overall, of all the emotional states (other than neutral), participants reported being happy more than being angry, relaxed, and sad while working. Happy workers tended to be motivated to work harder, which increased their productivity. Previous studies have shown that happy workers are more likely to be high performers $[38,49,57]$. We measured happiness in different ways to previous studies, but our results confirmed their findings.

Although we expected a significant negative relationship between anger and productivity, this was not the case. The regression results did not reveal that anger was associated with productivity. This was despite the fact that workers reported being angry for a non-trivial portion of time during their working hours. This suggested that, even in a distressed state, workers could maintain a competent level of productivity. This was also the case for sad emotional states; however, participants reported being in a sad state quite infrequently. The fact that productivity was not significantly related to angry and sad emotional states contradicts the results of past studies. For instance, Yang and Hung [48] found that sad people do not value effort highly. Moreover, sad people feel there are more obstacles to attaining goals, which could reduce their self-efficacy and willingness to work toward a challenging and difficult goals. One possible reason for the conflicting findings between the present and previous studies could be that emotion was operationalized and measured differently. For instance, most previous studies did not examine in-the-moment emotionality, but the present study did.

In the present study, participants reported a small amount of anger, sadness, and relaxation, but these states did not seem to impact productivity. One possible reason for this could be the nature of the work observed in the present study. Painting toys is a simple task, which only requires following a few procedures. While sufficient levels of concentration and emotional engagement are advantageous, these are not essential for successful performance. Additionally, workers' emotional states fluctuated frequently throughout the day, making it difficult to pinpoint whether one particular state at a given time could influence productivity within that moment. This was evident in the variable effective patterns outlined in Figure 1, which showed workers' in-the-moment emotional status and conversation time on a given day. Although a happy emotional state (shown in green) was present most of the time, it was not steady but interrupted by different emotional states (red represents ager, yellow represents relaxation, and gray represents neutral) and conversation time (blue). Furthermore, it was possible that the preponderance of happy and neutral states might have counteracted any experience of anger, relaxation, and sadness. These results supported the findings of Hayano et al. [46], who also observed large variability in reported emotional states among participants. 


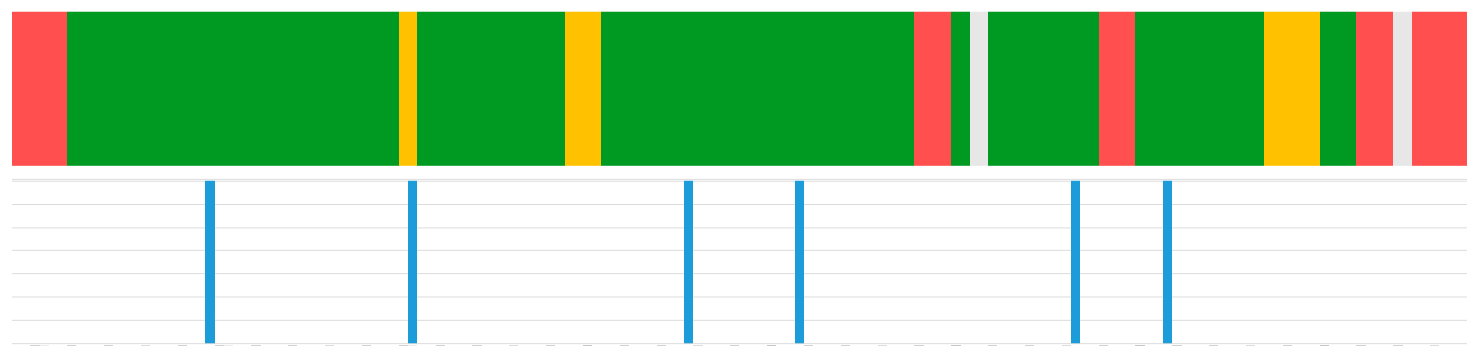

Figure 1. Emotional status of a worker on a working day. The green (happy), red (angry), yellow (relaxed), and gray (neutral) colors represent the distribution of workers' in-the-moment emotional states during a day. The blue bar underneath the emotion graph indicates the amount of conversation. The horizontal line shows the time span during a day, and the vertical line shows workers' emotional status and conversation during that time.

Our study provided evidence for a significant negative relationship between time spent conversing and productivity, suggesting that conversational interactions were associated with diminished productivity. This relationship was significant irrespective of any reported emotional state, biometric variable, or demographic factor. Workers spent approximately $14 \%$ of each shift conversing with each other. Since the completion of the work tasks required a specific amount of time, engaging in conversation seemed to hamper efficiency. However, it could be the case that for some tasks, time spent conversing could be beneficial. For instance, for highly technical and sophisticated tasks, employees may need to consult each other. However, given that the task assessed in the present study required unskilled labor, conversational time was likely a hindrance rather than a benefit.

The present results have several implications for operational and human resources strategies. The significant positive relationship between happiness and worker productivity suggested a need to consider emotionality when producing workflow designs that could help ensure a pleasant working environment. The KP Beau Lao Co. is situated in one of the special economic zones in Laos, which is referred to as the Savannakhet special economic zone. Special economic zones have been established to attract foreign direct investment, which offers many incentives for investors to obtain cheap labor. Attracting such investments is one of the ways in which developing and emerging economic countries have formulated their development strategies. In anticipation of efforts to reduce foreign investment growth in China (mostly due to increased labor costs), the special economic zones within ASEAN countries have become a solid destination for foreign investment. However, the flow of investment into these zones over the years has increased competition among countries and companies. For instance, the KP Beau Lao Co. was initially in China but later moved to Laos, owing to increasing labor costs. In recent years, labor costs and turnover rates have begun to increase within ASEAN countries, including Laos. Workers often switch to companies offering higher wages. Thus, apart from wages, companies could retain employees by creating pleasant work environments. It is important to understand workers' emotional states to address worker retention. The KP Beau Lao Co. is concerned with this issue and trying to ensure good working conditions, which has helped reduce their turnover ratio. While the present study did not explicitly examine worker turnover, lower employee turnover is consistent with the implication that pleasant working environments influence productivity and employee commitment. This also applies to other countries with special economic zones facing competition from within and outside their borders.

\section{Conclusions}

The present study examined how workers' emotional states were associated with productivity. While worker productivity is a well-studied area, no prior research had examined how on-job emotional states are associated with productivity. A wearable biometric device that records workers' emotionality during working hours made it possible to examine more objectively the relationship between workers' mental status and productivity. 
The regression results revealed that happiness was significantly associated with increased productivity, while anger, sadness, and relaxation were not significantly predictive. We argued that the nature of the job and variability in workers' in-the-moment emotional states throughout a shift could help explain why happiness was the only significant predictive emotion. Our study found that workers remained in happy emotional states most of the time while working, compared to other emotional states. Since happy workers are usually the high performers, the significantly positive relationship between happiness and productivity is to be expected. On the other hand, participants reported being in angry, sad, and relaxed states quite infrequently. Painting toys is a simple task, which does not require a high level of concentration and skills, but requires following a few basic procedures. While sufficient levels of concentration and emotional engagement are advantageous, these are not essential for successful performance. Additionally, we observed that, regardless of emotional state, worker productivity was negatively associated with conversational behaviors during a shift. Since the completion of the work tasks requires a specific amount of time, engaging in conversation during the working hours seems to reduce efficiency. While time spent conversing could be beneficial for some technical and sophisticated tasks where employees need to consult each other, given that the task assessed in the present study required unskilled labor, conversational time was likely a hindrance rather than a benefit.

A few study limitations should be noted. A lack of emotionality, as determined using the biometric device, was presumed to reflect the presence of neutral effect among workers. However, we could not rule out the possibility that technical errors caused disruptions in the recording of emotional states. Another limitation was the number of observations made during the study. Workers were assessed only over three days, which might not have allowed enough time to obtain a variable range of emotional states and resultant links with productivity. Finally, it was possible that the evidence of a positive relationship between happiness and productivity was influenced by the biased gender distribution of our study. In our sample, 14 out of 15 workers were female, which implied that the evidence of the relationship between happiness and productivity applies mainly to women. Thus, the results of this study should be generalized cautiously. Despite these limitations, the present study provided prima facie evidence of how on-job emotional states might influence productivity. Future research needs to be directed towards finding a more generalized impact of emotional states on workers' productivity. Since the scope of the current study was limited to the line workers where technical skills were mostly required to conduct the job, it would be interesting to observe whether emotional conditions play different roles in other functional areas where sophisticated knowledge is required. Furthermore, the research could be extended to other sectors where employees work in a stressful environment, such as transportation and healthcare services.

These results have significant implications for organizational management in terms of designing work schedules and managing human resources. The changes in workers' emotional state during working hours is likely to have an important influence on productivity. Thus, management could improve productivity by maximizing workers' positive emotional experiences in the organizational environment. Furthermore, happy workers are not only high performers but also tend to be loyal to the organization. As a result, organizations could reduce the cost of staff turnover as well as ensuring higher productivity by maintaining an environment that makes workers happy.

Supplementary Materials: The following is available online at http://www.mdpi.com/2071-1050/12/4/1544/s1, Table S1: correlation matrix.

Author Contributions: Conceptualization, Y.K.; Methodology, Software, Validation, Formal Analysis, Investigation, Resources, Data Curation, Y.K., M.S.R.K., S.W., and P.B.; Writing - Original Draft Preparation, Y.K., M.S.R.K., S.W., and P.B.; Writing - Review and Editing, Y.K. and M.S.R.K.; Visualization, Y.K. and M.S.R.K.; Supervision, Y.K.; Project Administration, Y.K.; Funding Acquisition, Y.K. and M.S.R.K. All authors have read and agreed to the published version of the manuscript. 
Funding: This research was supported by JSPS KAKENHI (Grant Numbers 19K13739, 15KK0083, and 19K13684), RISTEX, JST. The funders had no role in the study design, data collection and analysis, decision to publish, nor preparation of the manuscript. This research was approved by the ethics committee of Hiroshima University (approval number E-1527).

Conflicts of Interest: The authors declare no conflict of interest.

\section{References}

1. Mathis, R.L.; Jackson, J.H. Human Resource Management, 13th ed.; South-Western Cengage Learning: Ohio, OH, USA, 2010.

2. Ferreira, A.; Du Plessis, T. Effect of online social networking on employee productivity. S. Afr. J. Inf. Manag. 2009, 11, 1-11. [CrossRef]

3. Baily, M.N.; Farrell, D.; Greenberg, E.; Henrich, J.D.; Jinjo, N.; Jolles, M.; Remes, J. Increasing Global Competition and Labor Productivity: Lessons from the US Automotive Industry; McKinsey Global Institute: San Francisco, CA, USA, 2005.

4. Hill, C.; Jones, G.; Schilling, M. Strategic Management Theory: An Integrated Approach; Cengage Learning: Boston, MA, USA, 2014.

5. Sels, L.; De Winne, S.; Delmotte, J.; Maes, J.; Faems, D.; Forrier, A. Linking HRM and small business performance: An examination of the impact of HRM intensity on the productivity and financial performance of small businesses. Small Bus. Econ. 2006, 26, 83-101. [CrossRef]

6. Oliner, S.D.; Sichel, D.E. The Resurgence of Growth in the Late 1990s: Is Information Technology the Story? J. Econ. Perspect 2000, 14, 3-22. [CrossRef]

7. Relich, M. The impact of ICT on labor productivity in the EU. Inform. Technol. Dev. 2017, 23, 706-722. [CrossRef]

8. Sharma, M.S.; Sharma, M.V. Employee engagement to enhance productivity in current scenario. Int. J. Comm. Bus. Manag. 2014, 3, 595-604.

9. Anik, L.; Aknin, L.B.; Norton, M.I.; Dunn, E.W.; Quoidbach, J. Prosocial bonuses increase employee satisfaction and team performance. PLoS ONE 2013, 8, e75509. [CrossRef]

10. Cropanzano, R.; Randall, C.A. Using social exchange theory to distinguish procedural from interactional justice. In Proceedings of the 14th Annual Conference of the Society for Industrial and Organizational Psychology, Atlanta, GA, USA, 30 April-2 May 1993.

11. Luthans, F.; Norman, S.M.; Avolio, B.J.; Avey, J.B. The mediating role of psychological capital in the supportive organizational climate-employee performance relationship. J. Org. Behav. 2008, 29, 219-238. [CrossRef]

12. Valletta, R.G. Declining job security. J. Labor. Econ. 1999, 17, S170-S197. [CrossRef]

13. Anwar, S.; Aslam, M.; Tariq, M.R. Temporary job and its impact on employee performance. Glob. J. Manag. Bus. Res. 2011, 11, 23-28.

14. Holzer, H.J. The determinants of employee productivity and earnings. Ind. Rel. 1990, 29, 403-422. [CrossRef]

15. Basu, S.; Fernald, J.G.; Shapiro, M.D. Productivity Growth in the 1990s: Technology, Utilization, or Adjustment? NBER Working Paper No. 8359; National Bureau of Economic Research: Cambridge, MA, USA, 2001.

16. Hempell, T. Computers and Productivity; Physica-Verlag: Heidelberg, Germany, 2006.

17. Productivity Commission of Australia. ICT Use and Productivity: A Synthesis from Studies of Australian Firms; Productivity Commission Working Paper; Productivity Commission: Canberra, Australia, 2004.

18. Gavin, W.T. Productivity and Technology. National Economic Trends; The Federal Reserve Bank of St. Louis: St. Louis, MI, USA, 1997.

19. Skirbekk, V. Age and Individual Productivity: A Literature Survey. In Vienna Yearbook of Population Research; Feichtinger, G., Ed.; Austrian Academy of Sciences Press: Vienna, Austria, 2003; pp. 133-153.

20. Dostie, B. Wages, Productivity and Aging. De. Econ. 2011, 159, 139-158. [CrossRef]

21. Lallemand, T.; Rycx, F. Are older workers harmful for firm productivity? De. Econ. 2009, 157, $273-292$. [CrossRef]

22. Garibaldi, P.; Oliveira Martins, J.; van Ours, J.C. Health, Longevity and Productivity; Oxford University Press: Oxford, UK, 2011.

23. Aubert, P.; Crépon, B. Age, Wage and Productivity: Firm-Level Evidence; INSEE: Paris, France, 2006. 
24. Göbel, C.; Zwick, T. Age and Productivity_Evidence from Linked Employer Employee Data; Discuss. Pap. No. 09-020; ent. Eur. Econ. Res. (Zew): Mannheim, Germany, 2009.

25. Börsch-Supan, A.; Weiss, M. Productivity and Age: Evidence from Work Teams at the Assembly Line. J. Econ. Age 2016, 7, 30-42. [CrossRef]

26. Calvo-Sotomayor, I.; Laka, J.P.; Aguado, R. Workforce ageing and labour productivity in Europe. Sustainability 2019, 11, 5851. [CrossRef]

27. Mahlberg, B.; Freund, I.; Cuaresma, J.C.; Prskawetz, A. Aging, productivity and wages in Austria. Labour. Econ. 2013, 22, 5-15. [CrossRef]

28. Bloom, D.E.; Sousa-Poza, A. Ageing and Productivity; FZID Discussion Paper 63-2012; Universität Hohenheim: Stuttgart, Germany, 2013.

29. Wu, R.; Cheng, X. Gender equality in the workplace: The effect of gender equality on productivity growth among the Chilean manufacturers. J. Dev. Areas 2016, 50, 257-274. [CrossRef]

30. Jones, P. Are educated workers really more productive? J. Dev. Econ. 2001, 64, 57-79. [CrossRef]

31. Belorgey, N.; Lecat, R.; Maury, T.P. Determinants of productivity per employee: An empirical estimation using panel data. Econ. Lett. 2006, 91, 153-157. [CrossRef]

32. Saxena, A. Workforce diversity: A key to improve productivity. Procedia Econ. Fin. 2014, 11, 76-85. [CrossRef]

33. Rasool, S.F.; Maqbool, R.; Samma, M.; Zhao, Y.; Anjum, A. Positioning depression as a critical factor in creating a toxic workplace environment for diminishing worker productivity. Sustainability 2019, 11, 2589. [CrossRef]

34. Boles, M.; Pelletier, B.; Lynch, W. The relationship between health risks and work productivity. J. Occup. Environ. Med. 2004, 46, 737-745. [CrossRef] [PubMed]

35. Bubonya, M.; Cobb-Clark, D.A.; Wooden, M. Mental health and productivity at work: Does what you do matter? Labour. Econ. 2017, 46, 150-165. [CrossRef]

36. Holden, L.; Scuffham, P.A.; Hilton, M.F.; Ware, R.S.; Vecchio, N.; Whiteford, H.A. Which health conditions impact on productivity in working Australians. J. Occup. Environ. Med. 2011, 53, 253-257. [CrossRef] [PubMed]

37. Saarni, C. Development of Emotional Competence; Guilford Press: New York, NY, USA, 1999.

38. Yuda, E.; Ogasawara, H.; Yoshida, Y.; Hayano, J. Comparison of emotional impacts of interaction with remote controlled plush media and those with video call applications. In Proceedings of the IEEE 6th Global Conference on Consumer Electronics (GCCE 2017), Nagoya, Japan, 24-27 October 2017.

39. DiMaria, C.H.; Peroni, C.; Sarracino, F. Happiness matters: Productivity gains from subjective well-being. J. Happiness Stud. 2019, 1-22. [CrossRef]

40. Frey, B.S. Consequences of happiness. In Economics of Happiness; Springer Briefs in Economics; Springer: Cham, Switzerland, 2018; pp. 21-23. [CrossRef]

41. Tenney, E.R.; Poole, J.M.; Diener, E. Does positivity enhance work performance? Why, when, and what we don't know. Res. Organ. Behav. 2016, 36, 27-46. [CrossRef]

42. Neumann, W.P.; Dul, J. Human factors: Spanning the gap between OM and HRM. Int. J. Operat. Prod. Manag. 2010, 30, 923-950. [CrossRef]

43. Ødegaard, F.; Roos, P. Measuring the contribution of workers' health and psychosocial work-environment on production efficiency. Prod. Operat. Manag. 2014, 23, 2191-2208. [CrossRef]

44. Gubler, T.; Larkin, I.; Pierce, L. Doing well by making well: The impact of corporate wellness programs on employee productivity. Manag. Sci. 2018, 64, 4967-4987. [CrossRef]

45. Ton, Z. The Good Jobs Strategy: How the Smartest Companies Invest. In Employees to Lower Costs and Boost Profits; Houghton Mifflin Harcourt: New York, NY, USA, 2014.

46. Hayano, J.; Tanabiki, T.; Iwata, S.; Abe, K.; Yuda, E. Estimation of emotions by wearable biometric sensors under daily activities. In Proceedings of the IEEE 7th Global Conference on Consumer Electronics (GCCE), Nara, Japan, 9-12 October 2018.

47. Davis, J. Two Awesome Hours: Science-Based Strategies to Harness your Best Time and Get your Most Important Work Done; Harper One: New York, NY, USA, 2015.

48. Yang, J.S.; Hung, H.V. Happy workers value effort, sad workers value reward. Int. J. Hum. Resour. Manag. 2017, 28, 1591-1624. [CrossRef]

49. Oswald, A.J.; Proto, E.; Sgroi, D. Happiness and productivity. J. Labor Econ. 2015, 33, 789-822. [CrossRef]

50. Russell, J. A circumplex model of affect. J. Pers. Soc. Psych. 1980, 39, 1161-1178. [CrossRef] 
51. Rubin, D.C.; Talerico, J.M. A comparison of dimensional models of emotion. Memory 2009, 17, $802-808$. [CrossRef] [PubMed]

52. Choi, K.H.; Junbeom, K.; Sang, K.; Min, J.K.; Yeon, H.R.; Ji-Eun, P. Is heart rate variability (HRV) an adequate tool for evaluating human emotions? A focus on the use of the International Affective Picture System (IAPS). Psychiatry Res. 2017, 251, 192-196. [CrossRef] [PubMed]

53. Valenza, G.; Antonio, L.; Enzo, P.S. The role of nonlinear dynamics in affective valence and arousal recognition. IEEE Trans. Affect. Comput. 2012, 3, 237-249. [CrossRef]

54. Lane, R.D.; Kateri, M.; Eric, M.R.; Kewei, C.; Geoffrey, L.A.; Julian, F.T. Neural correlates of heart rate variability during emotion. NeuroImage 2009, 44, 213-222. [CrossRef]

55. Mitchell, R.J.; Bates, P. Measuring health-related productivity loss. Popul. Health Manag. 2011, 14, 93-98. [CrossRef]

56. Pelletier, B.; Boles, M.; Lynch, W. Change in health risks and work productivity over time. J. Occup. Environ. Med. 2004, 46, 746-754. [CrossRef]

57. Bellet, C.S.; De Neve, J.-E.; Ward, G. Does Employee Happiness Have an Impact on Productivity; CEP Discussion Papers dp1655; Centre for Economic Performance, London School of Economics and Political Science: London, UK, 2019.

(C) 2020 by the authors. Licensee MDPI, Basel, Switzerland. This article is an open access article distributed under the terms and conditions of the Creative Commons Attribution (CC BY) license (http://creativecommons.org/licenses/by/4.0/). 